\title{
Seasonal variation in Population dynamics of phytoplankton in Guthia Taal, Wetland of Bahraich (U. P.) India
}

Rajiv Ranjan' ${ }^{1}$ and ${ }^{*}$ Sadguru Prakash ${ }^{2}$

\author{
'Department of Botany' \\ ${ }^{2}$ Department of Zoology, \\ M.L.K. (P.G.) College, BALRAMPUR (U.P.) \\ ${ }^{*}$ Corresponding Author \\ Email: sadguruprakash@gmail.com
}

Received : 25.08.2020; Revised : 15.09.2020; Accepted : 22.09.2020

\begin{abstract}
Guthia taal is a large, shallow and horse shoe shaped wetland of tarai region of eastern U.P. The seasonal variation of phytoplankton density and diversity were studied for a period of one year. In the present study total 31 genera of phytoplankton were identified. Out of 31, thirteen belong to Chlorophyceae, 10 Bascillariophyceae, 6 Cyanophyceae and 2 Euglenophyceae. The annual density shows that Chlorophyceae dominates and constituted $51.57 \%$ of the total phytoplankton population was followed by Bascillariophyceae $(27.37 \%)$, Cyanophyceae $(16.45 \%)$ and Euglenophyceae $(4.61 \%)$. However, the overall phytoplankton was found maximum in summer, medium in winter and lowest in monsoon season.

Figure : $00 \quad$ References : 15

Table : 01

KEY WORDS : Phytoplankton, Population dynamics, Wetland.
\end{abstract}

\section{Introduction}

Wetlands are areas where water is primary factor controlling the environment and the associated plants and animal life. They occur where the water Table is at or near the surface of the land, or where the land is covered by water. Wetlands are among the world's most productive environments. They are cradles of biological diversity, providing the water and primary productivity upon which countless species of plants and animals depend for survival ${ }^{9}$. They support high concentrations of birds, mammals, reptiles, amphibians, fish and invertebrate species.

Biodiversity is the 'foundation of human life' on earth because each organism plays an important role and helps in producing more productive and stable ecosystem which has the ability to survive in stress conditions ${ }^{8}$. Environmental conditions play a key role in defining the function and distribution of organisms, in combination with other factors. Environmental changes have had enormous impacts on biodiversity patterns in the past and will remain one of the major drivers of biodiversity patterns in the future ${ }^{10}$. The biodiversity helps to maintain the ecological balance.

Population dynamic, density and diversity of plankton in a waterbody are of great importance in imposing sustainable management policies as they vary from location to location and aquatic systems within the same location. The inadequate knowledge of plankton and their dynamics is a major drawback for the better understanding of the life process of fresh water bodies. Planktonic populations on which whole aquatic life depends is directly or indirectly governed by many biological conditions and tolerances of organisms to variations in one or more of these conditions ${ }^{11}$. Phytoplanktons are the basic components of aquatic ecosystems and hence change in phytoplankton population has a direct link with the changes of water quality of any waterbody. Phytoplankton serves as a food for development and growth of zooplankton. Some of phytoplankton species give reliable information about pollution status of aquatic bodies. So, these are called good indicators of water quality because they are strongly affected by environmental conditions and respond quickly. Thus the population dynamics of plankton has a great importance for imposing sustainable environmental management policies like Environmental Impact Assessment (EPA).

Though numerous works on phytoplankton diversity are being reported from different parts of India but there is scarcity of reports from freshwater lentic waterbody of 
eastern Uttar Pradesh except some work. ${ }^{7,13}$ So, the present study was an attempt for studying phytoplankton dynamics of Guthia Taal of Bahraich district of eastern U.P.

\section{STUDY AREA:}

Guthia Taal is a large shallow perennial horse shoe shaped lentic waterbody. The total catchment area of wetland is about 75.9 ha. Out of 75.9 ha, $25.3 \mathrm{ha}$ is situated in Guthia, 25.3ha in Rucknapur, 22.77ha in Dihawa Sher Bahadur Singh and 2.53ha in Nawgeya villages, of Kaiserganj Tahseel of district Bahraich. But in summer season its water spread area becomes reduced up to $37.95 \mathrm{ha}$. It is situated between the latitude $27.2537^{\circ} \mathrm{N}-81.54313^{\circ} \mathrm{E}$. The Taal is enriched with several types of vegetation such as Nymphaea, Nelumbo and Nymphya as well as aquatic birds like Duck, Saras and Bagula. The water of Taal is used for agriculture and fish culture. The abundant food attracts hundreds of resident and migratory birds including Siberian crane during winter season.

\section{Material and Methods}

Phytoplankton samples from three sites located in three different villages were collected monthly with plankton net of bolting no. 25 with a mesh size $25 \mu$ attached with a collection tube at the base of net throughout the year (January 2019 to December 2019, between 9.00 to $10.00 \mathrm{am}$ ). Fifty liter of surface water was sieved through the plankton net and sample was collected inside the collection tube. The sample was transferred to plastic bottle and preserved in $70 \%$ alcohol. Phytoplankton productivity was measured by using Sedge Wick Rafter Plankton counting cell and quantities are expressed as unit per liter of the taal water. The diversity of phytoplankton was studied under light microscope with magnification 10X initially and followed by $40 \mathrm{X}$. The specimens were identified. . $^{1,6,15}$

\section{Result and Discussion}

Phytoplankton is the basic component of aquatic ecosystems and hence change in phytoplankton population has a direct link with the change of water quality in any aquatic ecosystem. They play a key role in solving some environmental problems, understanding aquatic ecosystems and the production of fish. Table- 1 shows the seasonal variations in diversity and density of different species of phytoplankton. Great fluctuation was observed in all the three seasons and also in three different sites of Guthia taal.

In the present study, the seasonal variation was observed in phytoplankton diversity and density. The phytoplankton diversity of Guthia taal comprised of 31 genera out of which 13 belonging to Chlorophyceae, 10 to Bascillariophyceae, 6 to Cyanophyceae and 2
Euglenophyceae. The annual density shows that Chlorophyceae dominated and constituted $51.57 \%$ of the total phytoplankton population was followed by Bascillariophyceae (27.37\%), Cyanophyceae (16.45\%) and Euglenophyceae (4.61\%)(Table-1). The phytoplankton density was recorded maximum in summer, moderate in winter and minimum in monsoon season at all the three sites (Table-1). Similar observations were also recorded by earlier workers $3,5,12,14$. Where as maximum density was observed in winter, moderate in summer and minimum in monsoon season in Alaknanda river. ${ }^{4}$

The qualitative study of phytoplankton revealed that the family Chlorophyceae was represented by genera Chlamydomonas, Closterium, Chlorella, Cledophora, Desmidium, Microspora, Nitella, Pediastrum, Scenedesmus, Sirogyra, Ulothrix, Volvox and Zygnema. The density of recorded genera of Chlorophyceae varied from 3.50 unit/L to 65.25 unit/L during study period. Chlorella was most dominant genus among Chlorophyceae group. In the present study maximum population of Chlorophyceae was observed in summer and minimum in monsoon season ${ }^{12}$.

The qualitative study of phytoplankton revealed that the family Bascillariophyceae was represented by genera Amphora, Cymbella, Diatoma, Fragilaria, Navicula, Nitzchia, Opephora ,Pinnularia, Synedra and Tubellaria. The density of recorded genera of Bascillariophyceae varied from 6.25 unit/L to 24.50 unit/L. During study period, Synedra was most dominant and Nitzchia was second dominant genus among Bascillariophyceae group. Maximum population of Bascillariophyceae was observed in summer and minimum in monsoon season. The present observation is similar to those made by other workers. ${ }^{5,12}$

The qualitative study of phytoplankton revealed that the family Cyanophyceae was represented by genera Anabaena, Anacystis, Gloecapsa, Microcystis, Oscillatoria and Spirulina. The density of recorded genera of Cyanophyceae varied from 5.50 unit/L to 23.50 unit/L during study period. Microcystis was most dominant genus among Cyanophyceae group. Maximum population of Cyanophyceae was observed in summer and minimum in monsoon season. The present observation is in conformity with the work of earlier researchers. 5,12,14

The qualitative study of phytoplankton revealed that the family Euglenophyceae was represented by two genera namely Euglena and Phacus. During study period the density of Euglenophyceae varied between 4.50 units/ $\mathrm{L}$ to 17.75 units/L. During study period, Euglena was dominant. Maximum population of Euglenophyceae was observed in summer and minimum in monsoon season. The present observations is similar to those observation made by other workers. ${ }^{5,12}$

Diversity of phytoplankton is an indication of purity 
TABLE-1 : Seasonal variation in diversity and density of phytoplankton (unit/ L) in Guthia Taal.

\begin{tabular}{|c|c|c|c|c|c|c|c|c|c|}
\hline \multirow[t]{2}{*}{ Phytoplankton } & \multicolumn{3}{|c|}{$\begin{array}{c}\text { Monsoon } \\
\text { (Mean July-Oct) }\end{array}$} & \multicolumn{3}{|c|}{$\begin{array}{c}\text { Winter } \\
\text { (Mean Nov.-Feb.) }\end{array}$} & \multicolumn{3}{|c|}{$\begin{array}{c}\text { Summer } \\
\text { (Mean Mar.- June) }\end{array}$} \\
\hline & s1 & S2 & s3 & s1 & S2 & s3 & S1 & S2 & S3 \\
\hline \multicolumn{10}{|c|}{ Chlorophyceae $51.57 \%$} \\
\hline Chlamydomonas sp. & 12.25 & 18.50 & 14.75 & 14.75 & 22.25 & 15.50 & 20.50 & 22.25 & 25.25 \\
\hline Closterium sp. & 7.50 & 11.25 & 9.25 & 9.25 & 11.50 & 12.75 & 15.25 & 19.25 & 14.50 \\
\hline Chlorella sp. & 13.50 & 19.25 & 16.75 & 43.25 & 38.25 & 34.75 & 45.25 & 57.25 & 45.50 \\
\hline Cledophora sp. & 8.50 & - & 7.50 & 9.75 & - & 4.25 & 12.25 & - & 11.50 \\
\hline Desmidium sp. & 18.50 & 26.25 & 25.25 & 37.25 & 28.25 & 19.25 & 31.50 & 52.25 & 49.50 \\
\hline Microspora sp. & 13.50 & 18.75 & 17.75 & 26.50 & 19.25 & 17.50 & 29.25 & 41.50 & 48.25 \\
\hline Nitella $s p$ & - & - & 5.25 & - & 8.25 & 10.75 & - & 8.25 & 25.50 \\
\hline Pediastrum sp. & 20.50 & 38.25 & 40.50 & 38.25 & 40.50 & 37.25 & 50.25 & 50.25 & 59.25 \\
\hline Scenedesmus sp. & 18.25 & 24.25 & 22.50 & 25.25 & 31.00 & 35.25 & 40.75 & 56.00 & 62.25 \\
\hline Sirogyra sp. & - & 3.50 & 5.50 & - & 4.50 & 8.50 & 4.25 & 9.50 & 11.25 \\
\hline Ulothrix sp. & 14.25 & 12.50 & 10.25 & 16.50 & 19.00 & 21.25 & 24.25 & 32.50 & 28.25 \\
\hline Volvox sp. & 9.50 & 8.50 & 9.25 & 12.25 & 16.00 & 18.25 & 15.25 & 18.50 & 21.50 \\
\hline Zygnema sp. & 4.50 & 8.50 & 7.50 & 9.00 & 15.25 & 20.50 & 11.50 & 18.00 & 25.25 \\
\hline Total & 140.75 & 189.50 & 192.0 & 242.00 & 254.00 & 255.75 & 300.25 & 385.50 & 427.75 \\
\hline
\end{tabular}

Bacillariophyceae(Diatoms) $27.37 \%$

\begin{tabular}{l|c|c|c|c|c|c|c|c|c}
\hline Amphora sp. & 10.50 & 12.50 & 10.25 & 14.75 & 15.50 & 13.75 & 17.75 & 19.25 & 19.50 \\
\hline Cymbella sp. & 9.50 & 8.25 & 7.50 & 10.75 & 11.25 & 12.25 & 21.50 & 20.50 & 23.75 \\
\hline Diatoma sp. & 9.75 & 11.25 & 10.50 & 12.25 & 14.25 & 15.50 & 24.50 & 23.75 & 26.25 \\
\hline Fragilaria sp. & 8.50 & 9.75 & 10.25 & 14.25 & 15.25 & 16.50 & 22.25 & 17.75 & 21.25 \\
\hline Navicula sp. & 8.50 & 7.75 & 9.25 & 10.25 & 9.25 & 11.25 & 16.50 & 14.50 & 18.25 \\
\hline Nitzchia sp. & 9.50 & 10.25 & 11.25 & 15.50 & 16.25 & 15.75 & 22.25 & 25.50 & 22.75 \\
\hline Opephora sp. & 5.50 & 4.25 & 6.25 & 9.50 & 8.50 & 9.25 & 10.75 & 12.50 & 11.75 \\
\hline Pinnularia sp. & 13.00 & 13.25 & 14.00 & 16.25 & 17.00 & 15.75 & 20.75 & 22.25 & 23.25 \\
\hline
\end{tabular}




\begin{tabular}{l|c|c|c|c|c|c|c|c|c}
\hline Synedra sp. & 12.50 & 13.50 & 14.25 & 16.25 & 14.50 & 15.25 & 22.25 & 24.50 & 23.25 \\
\hline Tubellaria sp. & 2.25 & 3.50 & 3.25 & 8.50 & 9.25 & 10.50 & 12.50 & 14.75 & 12.25 \\
\hline Total & 99.50 & 94.25 & 96.75 & 128.25 & 131.00 & 135.75 & 191.00 & 195.25 & 197.25 \\
\hline
\end{tabular}

Cyanophyceae (Blue Green Algae) $16.45 \%$

\begin{tabular}{l|c|c|c|c|c|c|c|c|c}
\hline Anabaena sp. & 10.25 & 11.25 & 10.00 & 13.75 & 14.25 & 15.50 & 19.25 & 21.50 & 18.75 \\
\hline Anacystis sp. & 8.50 & 7.75 & 9.25 & 10.25 & 11.25 & 13.25 & 14.25 & 16.25 & 17.00 \\
\hline Gloecapsa sp. & 7.25 & 8.00 & 7.75 & 10.25 & 11.00 & 12.25 & 15.25 & 16.50 & 16.75 \\
\hline Microcystis sp. & 15.25 & 18.00 & 18.25 & 20.75 & 23.25 & 22.50 & 25.25 & 28.50 & 27.75 \\
\hline Oscillatoria sp. & 5.50 & 6.00 & 5.75 & 9.25 & 9.50 & 9.00 & 11.25 & 14.25 & 13.50 \\
\hline Spirulina sp. & 9.50 & 9.75 & 8.75 & 12.25 & 14.25 & 15.75 & 18.25 & 19.50 & 20.25 \\
\hline Total & 58.25 & 60.75 & 59.75 & 76.50 & 83.50 & 88.25 & 103.50 & 116.50 & 114.00 \\
\hline
\end{tabular}

Euglenophyceae $4.61 \%$

\begin{tabular}{l|c|c|c|c|c|c|c|c|c}
\hline Euglena sp. & 9.00 & 10.25 & 8.75 & 12.25 & 14.25 & 15.50 & 17.75 & 16.50 & 17.25 \\
\hline Phacus sp. & 4.50 & 5.25 & 5.50 & 9.25 & 11.25 & 10.00 & 13.25 & 14.25 & 15.25 \\
\hline Total & 13.50 & 15.50 & 14.25 & 21.50 & 25.50 & 25.50 & 31.00 & 30.75 & 32.50 \\
\hline
\end{tabular}

and the use of community structure to assess pollution is conditioned by four assumptions: the natural community will evolve towards greater species complexity which eventually stabilizes; this process increases the functional complexity of the system; complex communities are more stable than simple communities, and pollution stress simplifies a complex community by eliminating the more sensitive species. The present study revealed that Guthia taal is a highly productive wetland in terms of better density of different phytoplankton communities.

\section{Conclusion}

The present study revealed that the Guthia taal was rich in density and diversity of phytoplankton. Total 31 genera of phytoplankton were identified. Out of 31, 13 belong to Chlorophyceae, 10 to Bascillariophyceae, 6 to Cyanophyceae and 2 Euglenophyceae. Chlorophyceae was dominated over rest of the phytoplankton population. However, the overall phytoplankton was found maximum in summer, medium in winter and lowest in monsoon season. Presence of Microcystis and Synedra species are the indicators of water pollution. Therefore, measures must be taken to minimize the water pollution by regulating human activities in watershed areas. Thus, keeping in view the importance of the study, steps should be taken for the conservation and maintenance of the freshwater wetland.

\section{References}

1. Alfred JRB, Bricice S, Issac ML. A guide to the study of freshwater organisms. Journal Madras Universal Supply. 1973; 1:103-151.

2. Edmondson WT. Fresh water Biology. IInd Edition. John Wiley and Sons. Inc. New York. 1992; 1248. 
3. Hassan FM, Taylor WD, Mayson MS, Al-Taee and Hassan JJ. Phytoplankton composition of Euphrates river in Al-Hindiya barrage and Kifil city region of Iraq. J.Environ. Biol. 2010; 31:343-350.

4. Jain CK, Malik DS, Tomar G. Seasonal variation in physico-chemical and phytoplankton diversity of Alakhanda River at Gharwal region (Uttarkhand). International journal of Fisheries and aquatic studies. 2018; 6(2):353-357.

5. Kumar M, Khare PK. Diversity of Plankton and their seasonal variation of density in the Yamuna river at Kalpi, district Jalaun (U.P.)India. Journal of Global Biosciences. 2015; 4(7):2720-2729.

6. Needham JJ, Needham PR. A Guide to the study of freshwater Biology, Charles Cthomas Publisher,US;. 1962.

7. Prakash S. Seasonal dynamics of Plankton in a fresh waterbody at Balrampur. GEOBIOS. 2001; 28(1):29-32.

8. Prakash S. Biodiversity Status and its Conservation in India.Biodiversity and Development: Challenges of $21^{\text {st }}$ century. Swaranjali publication, Ghaziabad, (U.P.).2019; pp33-41. ISBN: 978-93-89703-08-5.

9. Prakash S. Conservation status of fishes reported from Semara Taal of District Siddharthnagar (U.P.). India. Internal Journal of Fauna and Biological Studies. 2020; 7(3): 21-24.

10. Prakash S, Srivastava S. Impact of Climate change on Biodiversity: An Overview. International Journal of Biological Innovations. 2019; 1(2): 60-65. DOI: https://doi.org/10.46505/IJBI.2019.1205.

11. Sarwade AB, Kamble NA. Plankton diversity in Krishna River, Sangli, Maharashtra. Journal of Ecology and Natural Environment. 2014; 6(4):174-181.

12. Shinde SE, Pathan TS, Sonawane DL. Seasonal variations and biodiversity of phytoplankton in HarsoolSavangidam, Aurangabad, India. J.Envi. Bio. 2012; 33: 643-647.

13. Sinha M, Prakash S, Ansari KK. Seasonal Dynamics of Phytoplankton population in Relation to abiotic factors of a fresh water pond developed from wasteland of Brick-kiln. Asian Jr. of Microbiol. Biotech. Env.Sc. 2002; 4(1) : 43-45.

14. Thirugnanmoorthy K, Selvaraju M. Phytoplankton diversity in relation to physico-chemical parameters of Gnanaprekasam Temple pond of Chidambaram in Tamilnadu, India. Rece. Res. In Sc. And Tech. 2009; 1(5): 235-238.

15. Wetzel RG, Likens GE. Limnologyical analyses, second edition Springer-verlag New York. 1991; 1-175. 